\title{
MODEL EKIVALEN-PI DARI PEMBANGKIT LISTRIK TENAGA ANGIN DENGAN GENERATOR ASINKRON UNTUK ANALISIS ALIRAN DAYA
}

\author{
Rudy Gianto*) \\ Jurusan Teknik Elektro, Universitas Tanjungpura \\ Jalan Prof. Dr. H. Hadari Nawawi, Pontianak 78124, Indonesia \\ ${ }^{*}$ Email: rudy.gianto@ee.untan.ac.id
}

\begin{abstract}
Abstrak
Operasi keadaan-tunak (steady-state) dari suatu sistem tenaga listrik biasanya ditentukan melalui analisis aliran daya. Makalah ini mengusulkan metode sederhana untuk mengikutsertakan model pembangkit listrik tenaga angin (PLTAn) dengan generator asinkron pada perhitungan aliran daya. Model yang diusulkan ini disebut model ekivalen-pi karena rangkaian ekivalen-pi dari generator asinkron atau induksi telah digunakan untuk membentuk model matematis dari PLTAn tersebut. Model rangkaian ekivalen-pi ini diperoleh dari rangkaian ekivalen keadaan tunak generator induksi (rangkaian T atau Y) yang kemudian, melalui transformasi Y-D, dikonversi menjadi rangkaian $\Pi$ atau D. Transformasi ini dilakukan untuk mempermudah penurunan model matematis dari PLTAn dimaksud. Model ini kemudian diintegrasikan pada algoritma aliran daya dan diselesaikan dengan metode Newton-Raphson dimana hasilnya kemudian digunakan untuk mengevaluasi operasi keadaan tunak sistem secara keseluruhan (termasuk PLTAn). Pada makalah ini, studi-studi perbandingan antara metode yang diusulkan (model ekivalen-pi) dan metode lain (model jaringan duaterminal) juga telah dilakukan dimana terlihat bahwa hasil-hasil dari kedua metode tersebut adalah sangat sesuai.
\end{abstract}

Kata Kunci: pembangkit listrik tenaga angin, analisis aliran daya, sistem tenaga

\begin{abstract}
Steady-state operation of an electric power system is usually determined by using power flow analysis. This paper proposes a simple method for incorporating asynchronous wind turbine generating system (WTGS) into power flow calculation. The proposed model is called equivalent-pi model because asynchronous or induction generator equivalentpi circuit of the WTGS has been used to formulate the WTGS mathematical model. The equivalent-pi circuit model is obtained based on the induction generator steady-state equivalent circuit ( $\mathrm{T}$ or $\mathrm{Y}$ circuit). The $\mathrm{T}$ or $\mathrm{Y}$ circuit is then converted into $\Pi$ or D circuit through the application of $\mathrm{Y}-\mathrm{D}$ transformation. The transformation has been carried out to simplify derivation of the WTGS mathematical model. The model is then integrated into the power flow algorithm and solved using Newton-Raphson method. The solution results are then used to evaluate steady-state operation of the whole system (including the WTGS). In this paper, comparison studies between the proposed method (equivalent-pi model) and other published method (two-port network model) have also been carried out where the results of the two methods have been found to be in exact agreement.
\end{abstract}

Keywords: wind turbine generating system, load flow analysis, power system

\section{Pendahuluan}

Angin merupakan energi terbarukan yang paling cepat perkembangan teknologinya dibandingkan jenis energi terbarukan lainnya. Hal ini terutama dikarenakan energi angin merupakan energi yang biayanya paling kompetitif bila dikonversikan ke energi listrik. Prinsip dasar dari sistem PLTAn didasarkan pada dua proses berikut: konversi energi kinetik dari udara bergerak (angin) menjadi energi mekanik, dan konversi energi mekanik menjadi energi listrik.

Akhir-akhir ini integrasi dari PLTAn pada sistem tenaga listrik (power grid) telah meningkat secara signifikan.
Selama empat tahun terakhir, kapasitas terpasang PLTAn dunia telah meningkat dengan tingkat pertumbuhan ratarata sebesar 14\% [1]. Pada akhir tahun 2017, kapasitas PLTAn total dunia adalah sekitar 539 GW. Kapasitas PLTAn sebesar ini dapat mencukupi lebih dari 5\% dari kebutuhan listrik dunia [2].

Walaupun penggunaan energi angin sebagai sumber energi listrik akhir-akhir ini semakin populer, namun dengan meningkatnya integrasi PLTAn pada sistem tenaga listrik dapat menimbulkan masalah operasional pada sistem tersebut. Hal ini terutama disebabkan oleh perilaku alamiah dari energi angin itu sendiri yang sifatnya fluktuatif. Hal ini pada gilirannya dapat 
mengganggu operasional suatu sistem tenaga listrik baik dari sisi keadaan tunaknya (steady-state) maupun dari sisi kestabilannya (dynamic).

Telah diketahui bahwa operasi keadaan tunak (steadystate) dari suatu sistem tenaga listrik biasanya dievaluasi melalui analisis aliran daya. Analisis aliran daya juga diperlukan sebagai dasar untuk analisis sistem tenaga lainnya seperti analisis kestabilan sistem. Langkah pertama dalam pengintegrasian suatu PLTAn pada analisis aliran daya adalah pemodelan dari PLTAn tersebut. Dengan demikian, pengembangan model dari PLTAn adalah sangat diperlukan agar ia dapat diikutsertakan dalam analisis aliran daya tersebut dan operasi keadaan mantapnya dapat dievaluasi.

Beberapa peneliti telah melakukan kajian tentang pemodelan dan integrasi PLTAn pada analisis aliran daya seperti yang dilaporkan pada [3] - [10]. Pada [3] - [5], suatu model matematik dari PLTAn telah dikembangkan dimana kemudian persamaan matematik ini (bersamasama dengan persamaan aliran daya yang telah ada) diselesaikan secara iteratif untuk mendapat solusi yang diinginkan. Pada [6], suatu metode untuk mengintegrasikan PLTAn pada analisis aliran daya sistem distribusi tenaga listrik telah diusulkan. Metode yang diusulkan tersebut didasarkan pada teori jaringan duaterminal (two-port network) dimana parameter-parameter dari generator induksi ditanamkan (embedded) pada konstanta-konstanta umum dari jaringan dua-terminal. Model matematis dari PLTAn kemudian diturunkan berdasarkan persamaan-persamaan dari teori jaringan dua-terminal tersebut.

Referensi [7] - [10] mengusulkan suatu metode untuk mengikut-sertakan model PLTAn kedalam program aliran daya standar. Model tersebut menambah dua bus (simpul), dua elemen seri, satu elemen shunt dan satu beban pada jaringan sistem tenaga yang ada. Dengan menggunakan metode ini, solusi aliran daya dapat dicari hanya dengan menggunakan program aliran daya standar. Namun demikian, penambahan simpul dan cabang mengakibatkan ukuran sistem pada analisis aliran daya menjadi bertambah besar dan jumlah persamaan yang harus diselesaikan juga semakin banyak.

Makalah ini mengusulkan metode sederhana untuk mengikutsertakan model PLTAn kecepatan tetap pada analisis aliran daya sistem tenaga listrik. Model tersebut dinamai model ekivalen-pi karena didasarkan pada rangkaian ekivalen-pi dari generator induksi PLTAn. Model rangkaian ekivalen-pi ini diperoleh dari rangkaian ekivalen keadaan tunak generator induksi (rangkaian $\mathrm{T}$ atau Y) yang kemudian, melalui transformasi $\mathrm{Y}-\mathrm{D}$, dikonversi menjadi rangkaian $\Pi$ (pi) atau $\mathrm{D}$. Transformasi ini dilakukan untuk mempermudah penurunan model matematis dari PLTAn tersebut. Kemudian, model untuk PLTAn dibentuk melalui persamaan-persamaan yang diperoleh dari rangkaian ekivalen-pi tersebut. Model yang diusulkan ini lebih sederhana dan dapat dengan mudah diikut-sertakan pada algoritma perhitungan aliran daya. Hasil-hasil pengujian memperlihatkan bahwa metode yang diusulkan tersebut adalah akurat dan valid, dimana perbandingan hasil antara metode yang diusulkan (model ekivalen-pi) dengan metode lain yang sebelumnya telah dipublikasikan (model tiga-simpul) memperlihatkan bahwa hasilnya adalah sangat sesuai.

\section{Metode \\ 2.1. Formulasi Masalah Aliran Daya}

Analisis aliran daya dapat didefinisikan sebagai perhitungan-perhitungan besar dan sudut fasa tegangan dari setiap bus yang ada pada sistem tenaga listrik untuk kondisi pembangkitan dan pembebanan tertentu. Setelah tegangan-tegangan bus ini dihitung, daya yang mengalir pada saluran transmisi serta rugi-rugi dayanya juga akan dapat ditentukan.

Perumusan masalah aliran daya dapat diperoleh melalui persamaan yang menggambarkan penampilan dari jaringan sistem tenaga dalam bentuk admitansi. Persamaan ini kemudian digabungkan dengan rumusan injeksi daya bus sehingga menghasilkan:

$S_{G i}-S_{L i}-V_{i} \sum_{j=1}^{n} Y_{i j}^{*} V_{j}^{*}=0$

dimana:

$S_{G i}=P_{G i}+j Q_{G i}$ : pembangkitan daya pada bus-i

$S_{L i}=P_{L i}+j Q_{L i}:$ pembebanan daya pada bus-i

$V_{i}=\left|V_{i}\right|\left\llcorner\delta_{i} \quad\right.$ : tegangan pada bus-i

$Y_{i j}=\left|Y_{i j}\right|\left\llcorner\theta_{i j}\right.$ : elemen-ij dari matriks admitansi

$n \quad$ : jumlah bus

Persamaan (1) merupakan sekumpulan persamaan nonlinear yang harus diselesaikan pada analisis aliran daya. Oleh karena analisis aliran daya biasanya dilakukan pada kondisi beban tertentu ( $P_{L}$ dan $Q_{L}$ diketahui), maka masing-masing bus akan dikarakterisasi melalui empat variabel yaitu: daya aktif yang dibangkitkan $\left(P_{G}\right)$, daya reaktif yang dibangkitkan $\left(Q_{G}\right)$, besar tegangan bus $(|V|)$, dan sudut tegangan bus $(\delta)$.

\section{Tabel 1. Jenis Bus dan Variabel}

\begin{tabular}{cccc}
\hline No & Jenis Bus & $\begin{array}{c}\text { Variabel Yang } \\
\text { Ditentukan }\end{array}$ & Variabel Yang Dicari \\
\hline 1 & $\begin{array}{c}\text { Referensi } \\
\text { (Slack) }\end{array}$ & $\mid$ V dan $\mathbb{}$ & $P_{G}$ dan $Q_{G}$ \\
2 & $\begin{array}{c}\text { Beban } \\
(P Q)\end{array}$ & $P_{G}=Q_{G}=0$ & $|V|$ dan $\|$ \\
3 & $\begin{array}{c}\text { Pembangkit } \\
(P V)\end{array}$ & $P_{G}$ dan $|V|$ & $Q_{G}$ dan $\|$ \\
\hline
\end{tabular}


Agar (1) dapat diselesaikan, biasanya pada analisis aliran daya didefinisikan tiga jenis bus: bus referensi, bus pembangkit dan bus beban. Pendefinisian ini mengakibatkan jumlah persamaan menjadi sama dengan jumlah variabel yang akan dihitung, dan masalah aliran daya dapat dicari solusinya. Secara lengkap variabelvariabel yang ditentukan nilainya dan yang akan dicari untuk setiap bus sistem tenaga diperlihatkan pada Tabel 1.

\subsection{Model Ekivalen-Pi dari PLTAn}

Gambar 1(a) memperlihatkan PLTAn yang terhubung pada bus- $k$ suatu sistem tenaga listrik [7] - [9]. Konverter energi listrik dari PLTAn adalah generator induksi rotorsangkar (GIRS). Secara terpisah, GIRS tersebut diperlihatkan pada Gambar 1(b) dengan input daya mekanik $P_{m}$ dan output daya listrik $S_{g}=P_{g}+j Q_{g}$.

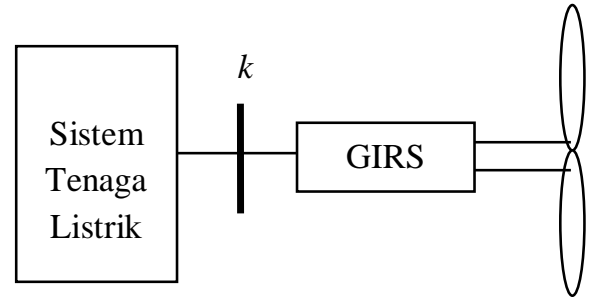

(a)

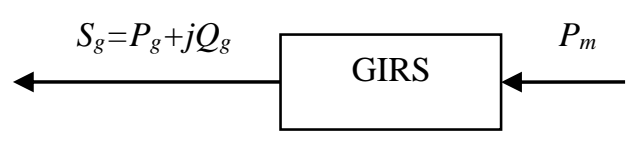

(b)

Gambar 1. PLTAn Terhubung Pada Sistem Tenaga

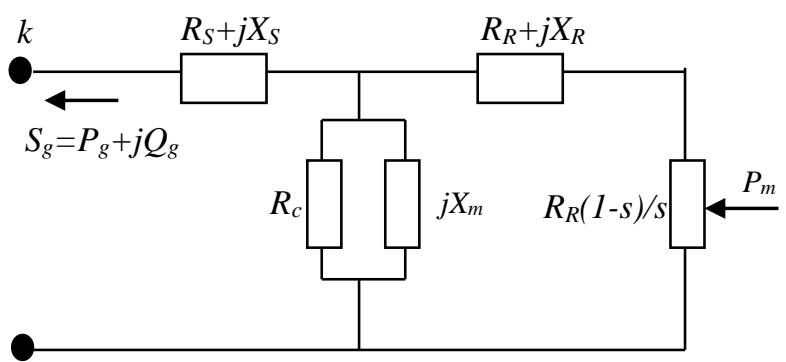

\section{Gambar 2. Rangkaian Ekivalen dari GIRS}

Rangkaian ekivalen keadaan tunak dari GIRS ditunjukkan pada Gambar 2 dimana $R_{S}, X_{S}, R_{R}, X_{R}, R_{c}$ dan $X_{m}$ berturutturut menyatakan resistansi stator, reaktansi bocor stator, resistansi rotor, reaktansi bocor rotor, resistansi rugi-rugi inti dan reaktansi magnetik. Resistansi $R_{R}(1-s) / s$ merupakan resistansi dinamik dan nilainya tergantung pada slip $s$. Daya dari resistansi ini menggambarkan input daya mekanik $P_{m}$ pada generator.
Perlu diingat bahwa $P_{m}$ juga merupakan daya yang dikirim oleh turbin angin ke generator induksi. Daya ini nilainya diketahui karena pabrik pembuat turbin biasanya menyediakan nilai-nilai untuk $P_{m}$ sebagai fungsi dari kecepatan angin.

Gambar 3(a) memperlihatkan rangkaian ekivalen GIRS dalam bentuk impedansi. Impedansi-impedansi $Z_{S}, Z_{R}$ dan $Z_{M}$ pada Gambar 3(a) diberikan oleh:

$$
\begin{aligned}
& Z_{S}=R_{S}+j X_{S} \\
& Z_{R}=R_{R}+j X_{R} \\
& Z_{M}=j R_{c} X_{m} /\left(R_{c}+j X_{m}\right)
\end{aligned}
$$

Sedangkan rangkaian pada Gambar 3(b) diperoleh dengan menerapkan transformasi Y-D pada rangkaian Gambar 3(a). Transformasi ini dilakukan untuk mempermudah penurunan model matematis dari PLTAn. Berdasarkan teori dasar rangkaian listrik, dapat ditunjukkan bahwa impedansi-impedansi $Z_{a}, Z_{b}$ dan $Z_{c}$ pada Gambar 3(b) diberikan oleh:

$$
\begin{aligned}
& Z_{a}=Z_{R}+Z_{M}+Z_{R} Z_{M} / Z_{S} \\
& Z_{b}=Z_{S}+Z_{M}+Z_{S} Z_{M} / Z_{R} \\
& Z_{c}=Z_{S}+Z_{R}+Z_{S} Z_{R} / Z_{M}
\end{aligned}
$$

Berdasarkan Gambar 3(b), rumusan untuk keluaran daya PLTAn $\left(S_{g}=P_{g}+j Q_{g}\right)$ dan masukan daya mekanik $\left(S_{m}=P_{m}+j 0\right)$ adalah sebagai berikut (penurunannya dapat dilihat pada Lampiran):

$$
\begin{aligned}
& S_{g}=\frac{1}{Z_{c}^{*}} V_{R}^{*} V_{S}-\left(\frac{1}{Z_{c}^{*}}+\frac{1}{Z_{b}^{*}}\right) V_{S}^{*} V_{S} \\
& S_{m}=\left(\frac{1}{Z_{c}^{*}}+\frac{1}{Z_{a}^{*}}\right) V_{R}^{*} V_{R}-\frac{1}{Z_{c}^{*}} V_{S}^{*} V_{R}
\end{aligned}
$$

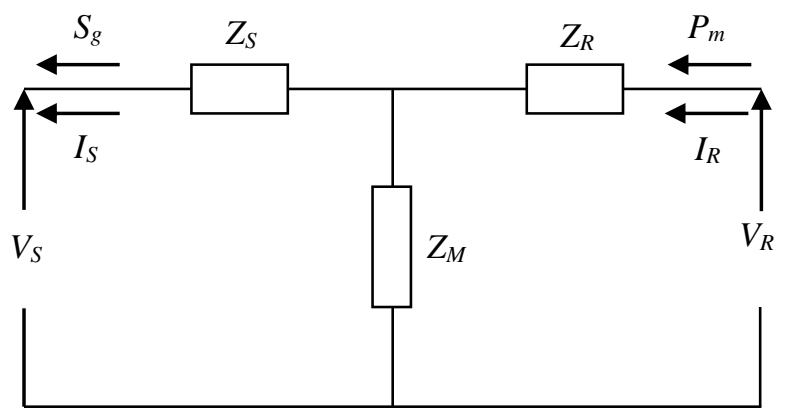

(a) 


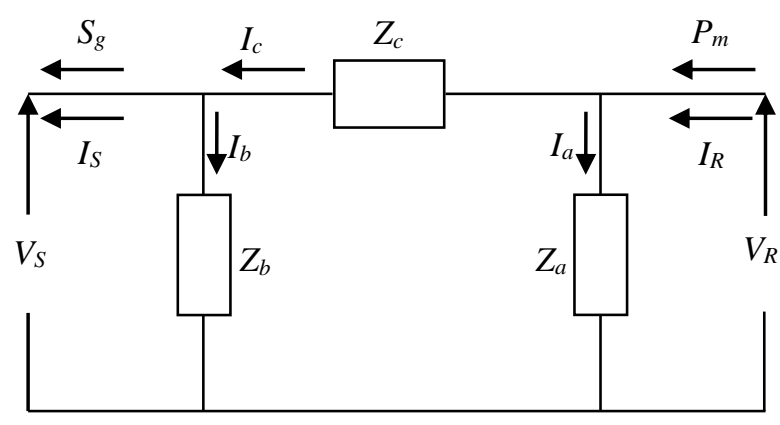

(b)

Gambar 3. Rangkaian Ekivalen dari GIRS dalam Bentuk Impedansi

Dengan mengatur kembali (4a) dan (4b), akan diperoleh:

$$
\begin{aligned}
& S_{g}-\frac{1}{Z_{c}^{*}} V_{R}^{*} V_{S}+\left(\frac{1}{Z_{c}^{*}}+\frac{1}{Z_{b}^{*}}\right) V_{S}^{*} V_{S}=0 \\
& S_{m}-\left(\frac{1}{Z_{c}^{*}}+\frac{1}{Z_{a}^{*}}\right) V_{R}^{*} V_{R}+\frac{1}{Z_{c}^{*}} V_{S}^{*} V_{R}=0
\end{aligned}
$$

Persamaan (5) merupakan usulan model matematis dari PLTAn. Integrasi dari model tersebut pada analisis aliran daya akan dibahas pada subbab berikut.

\subsection{Integrasi Model PLTAn}

Untuk sistem tenaga listrik yang mengandung PLTAn, solusi masalah aliran dayanya dapat dicari dengan menyelesaikan secara simultan persamaan- persamaan nonlinear (1) dan (5). Perlu dicatat bahwa $V_{S}$ pada (5) merupakan tegangan stator dari GIRS (atau sama dengan tegangan pada bus PLTAn). Sedangkan $V_{R}=\left|V_{R}\right|\llcorner\alpha$ adalah tegangan rotor GIRS.

Dengan demikian, (5) adalah persamaan tambahan pada rumusan masalah aliran (1). Persamaan ini muncul sebagai akibat adanya integrasi PLTAn pada sistem. Sedangkan variabel tambahan yang harus dicari solusinya adalah daya yang dibangkitkan oleh PLTAn $\left(S_{g}\right)$ dan tegangan rotor $\left(V_{R}\right)$. Secara lengkap, variabel-variabel yang ada pada setiap bus untuk sistem tenaga yang mengandung PLTAn diperlihatkan pada Tabel 2. Terlihat bahwa untuk bus PLTAn, variabel yang ditentukan nilainya adalah $P_{G}=Q_{G}=0$ (karena bus ini tidak mengandung pembangkit konvensional). Sedangkan variabel yang akan dicari nilainya adalah $P_{g}, Q_{g},|V|, \delta$, $\left|V_{R}\right|$, dan $\alpha$.

\begin{tabular}{|c|c|c|c|}
\hline No & Jenis Bus & $\begin{array}{l}\text { Variabel Yang } \\
\text { Ditentukan }\end{array}$ & Variabel Yang Dicari \\
\hline 1 & $\begin{array}{l}\text { Referensi } \\
\text { (Slack) }\end{array}$ & $|V|$ dan $\mid=0$ & $P_{G}$ dan $Q_{G}$ \\
\hline 2 & Beban (PQ) & $P_{G}=Q_{G}=0$ & |V| dan | \\
\hline 3 & $\begin{array}{l}\text { Pembangkit Non- } \\
\text { PLTAn (PV) }\end{array}$ & $P_{G}$ dan $|V|$ & $Q_{G}$ dan \\
\hline 4 & PLTAn & $P_{G}=Q_{G}=0$ & $\begin{array}{c}P_{g}, Q_{g},|V|,[] \\
\left|V_{R}\right|, \text { dan } \mid \\
\end{array}$ \\
\hline
\end{tabular}

Tabel 2. Jenis Bus dan Variabel Sistem dengan PLTAn

\section{Hasil Dan Analisa}

\subsection{Sistem Test}

Model dan metode pengintegrasian PLTAn seperti yang diusulkan pada Bagian 2 akan diuji dengan menerapkannya pada sistem tenaga listrik yang diagram segarisnya ditunjukkan pada Gambar 4. Sistem ini didasarkan pada sistem 5-bus [12]. Sistem 5-bus ini kemudian dimodifikasi dengan menambahkan PLTAn kecepatan tetap pada bus-5. Data sistem diperlihatkan pada Tabel 3 - 5 dimana semua data adalah dalam pu dengan dasar $100 \mathrm{MVA}$.

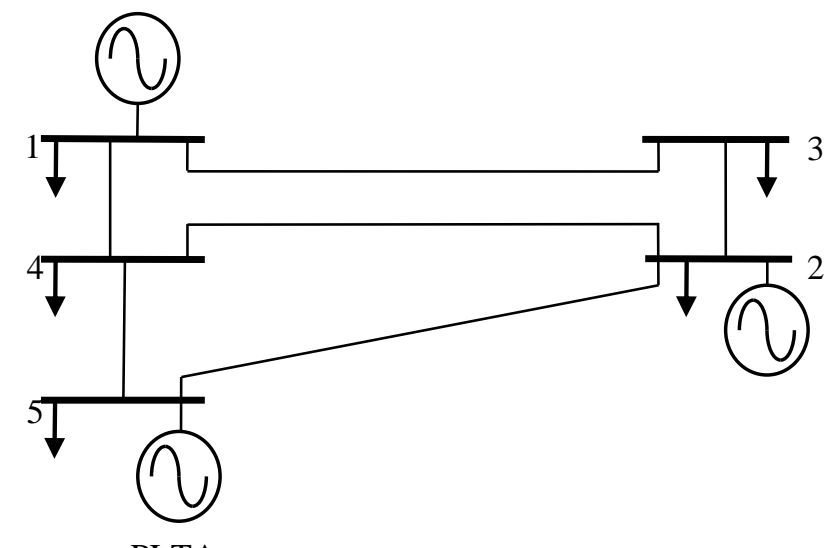

PLTAn

\section{Gambar 4. Sistem 5-Bus}

Tabel 3. Impedansi Seri dan Admitansi Saluran

\begin{tabular}{cccc}
\hline Sal. & $\begin{array}{c}\text { Bus } \\
\mathbf{p - q}\end{array}$ & $\begin{array}{c}\text { Impedansi Seri } \\
(\mathbf{Z})\end{array}$ & $\begin{array}{c}\text { Admitansi Shunt } \\
(\text { Ysh/2) }\end{array}$ \\
\hline 1 & $1-3$ & $0,042+j 0,168$ & $\mathrm{j} 0,0205$ \\
2 & $1-4$ & $0,031+\mathrm{j} 0,126$ & $\mathrm{j} 0,0155$ \\
3 & $2-3$ & $0,031+\mathrm{j} 0,126$ & $\mathrm{j} 0,0155$ \\
4 & $2-4$ & $0,053+\mathrm{j} 0,210$ & $\mathrm{j} 0,0255$ \\
5 & $2-5$ & $0,084+\mathrm{j} 0,336$ & $\mathrm{j} 0,0410$ \\
6 & $4-5$ & $0,063+\mathrm{j} 0,252$ & $\mathrm{j} 0,0305$ \\
\hline
\end{tabular}

\begin{tabular}{|c|c|c|c|c|c|}
\hline Bus & 19 & $\square$ & Pembangkitan & Beban & Ket. \\
\hline 1 & 1,04 & 0 & - & $0,65+j 0,30$ & Slack \\
\hline 2 & 1,02 & - & $1,8+j-$ & $0,70+j 0,40$ & PV \\
\hline 3 & - & - & 0 & $1,15+j 0,60$ & $P Q$ \\
\hline 4 & - & - & 0 & $0,85+j 0,40$ & $P Q$ \\
\hline 5 & - & - & - & $0,70+j 0,30$ & PLTAn \\
\hline
\end{tabular}

Tabel 4. Tegangan dan Daya Bus 
Tabel 5. Parameter-Parameter GIRS dari PLTAn

\begin{tabular}{ccccccc}
\hline Parameter & $\boldsymbol{R}_{\mathbf{1}}$ & $\boldsymbol{X}_{\boldsymbol{1}}$ & $\boldsymbol{R}_{\mathbf{2}}$ & $\boldsymbol{X}_{\mathbf{2}}$ & $\boldsymbol{R}_{\boldsymbol{c}}$ & $\boldsymbol{X}_{\boldsymbol{m}}$ \\
\hline Nilai & 0,02 & 0,10 & 0,018 & 0,18 & 50 & 3,2 \\
\hline
\end{tabular}

\subsection{Hasil dan Pembahasan}

Perhitungan aliran daya pada makalah ini dilakukan untuk berbagai nilai $\mathrm{Pm}$ (yaitu dari $0,1 \mathrm{~s} / \mathrm{d}$ 1,0 pu). Semua perhitungan tersebut dilakukan pada komputer pribadi $(P C)$ dengan bantuan perangkat lunak MATLAB $^{\mathrm{TM}}$, dimana algoritma perhitungan diimplementasikan dalam bentuk kode $m$-file.

Hasil dari perhitungan tegangan pada bus PLTAn (bus 5) dan keluaran daya listrik PLTAn berturut-turut diperlihatkan pada Tabel 6 dan 7. Sebagai pembanding, hasil dari metode lain (metode jaringan dua-terminal) seperti yang diusulkan pada [6] juga diperlihatkan pada tabel-tabel tersebut.

Tabel 6. Besar Tegangan Pada Bus PLTAn

\begin{tabular}{ccc}
\hline$P m$ & Metode Yang Diusulkan & $\begin{array}{c}\text { Metode Jaringan } \\
\text { Dua-Terminal }\end{array}$ \\
\hline 0,1 & 0,8765 & 0,8765 \\
0,2 & 0,8811 & 0,8811 \\
0,3 & 0,8836 & 0,8836 \\
0,4 & 0,8841 & 0,8841 \\
0,5 & 0,8826 & 0,8826 \\
0,6 & 0,8786 & 0,8786 \\
0,7 & 0,8718 & 0,8718 \\
0,8 & 0,8611 & 0,8611 \\
0,9 & 0,8441 & 0,8441 \\
1,0 & 0,8106 & 0,8106 \\
\hline
\end{tabular}

Tabel 7. Daya Listrik Yang Dibangkitkan PLTAn

\begin{tabular}{ccc}
\hline$P m$ & Metode Yang Diusulkan & $\begin{array}{c}\text { Metode Jaringan } \\
\text { Dua-Terminal }\end{array}$ \\
\hline 0,1 & $0,0836-\mathrm{j} 0,2373$ & $0,0836-\mathrm{j} 0,2373$ \\
0,2 & $0,1819-\mathrm{j} 0,2517$ & $0,1819-\mathrm{j} 0,2517$ \\
0,3 & $0,2791-\mathrm{j} 0,2723$ & $0,2791-\mathrm{j} 0,2723$ \\
0,4 & $0,3754-\mathrm{j} 0,2993$ & $0,3754-\mathrm{j} 0,2993$ \\
0,5 & $0,4707-\mathrm{j} 0,3332$ & $0,4707-\mathrm{j} 0,3332$ \\
0,6 & $0,5647-\mathrm{j} 0,3749$ & $0,5647-\mathrm{j} 0,3749$ \\
0,7 & $0,6573-\mathrm{j} 0,4263$ & $0,6573-\mathrm{j} 0,4263$ \\
0,8 & $0,7479-\mathrm{j} 0,4906$ & $0,7479-\mathrm{j} 0,4906$ \\
0,9 & $0,8353-\mathrm{j} 0,5752$ & $0,8353-\mathrm{j} 0,5752$ \\
1,0 & $0,9149-\mathrm{j} 0,7112$ & $0,9149-\mathrm{j} 0,7112$ \\
\hline
\end{tabular}

Tabel 6 menunjukkan bahwa tegangan pada terminal PLTAn nilainya cukup rendah. Hal ini disebabkan karena adanya konsumsi daya reaktif oleh generator induksi PLTAn. Hasil ini juga dikonfirmasi oleh Tabel 7 dimana daya reaktif yang disuplai PLTAn bernilai negatif yang berarti generator induksi tersebut menyerap daya reaktif dari sistem. Bila sistem tidak mampu menyediakan daya reaktif tersebut, maka tegangan akan menjadi turun.
Untuk menaikkan besar tegangan dan memperbaiki profil tegangan, kapasitor shunt biasanya dipasang pada terminal PLTAn kecepatan tetap. Tabel 8 dan 9 memperlihatkan hasil-hasil perhitungan untuk PLTAn yang dilengkapi dengan kapasitor shunt sebesar 0,5 pu. Seperti yang telah diperkirakan, pemasangan kapasitor shunt dapat memperbaiki profil tegangan karena daya reaktif yang diperlukan disuplai oleh kapasitor tersebut, seperti ditunjukkan pada Tabel 8.

Tabel 8. Besar Tegangan Bus PLTAn Dengan Kapasitor

\begin{tabular}{ccc}
\hline$P m$ & Metode Yang Diusulkan & $\begin{array}{c}\text { Metode Jaringan } \\
\text { Dua-Terminal }\end{array}$ \\
\hline 0,1 & 0,9668 & 0,9668 \\
0,2 & 0,9710 & 0,9710 \\
0,3 & 0,9739 & 0,9739 \\
0,4 & 0,9754 & 0,9754 \\
0,5 & 0,9755 & 0,9755 \\
0,6 & 0,9742 & 0,9742 \\
0,7 & 0,9713 & 0,9713 \\
0,8 & 0,9667 & 0,9667 \\
0,9 & 0,9598 & 0,9598 \\
1,0 & 0,9501 & 0,9501 \\
\hline
\end{tabular}

Perbandingan hasil antara metode yang diusulkan dengan metode pada [6] juga memperlihatkan bahwa hasilnya adalah sangat sesuai (lihat Tabel 6-9). Hal ini mengkonfirmasi bahwa model yang diusulkan adalah akurat dan valid untuk digunakan sebagai cara untuk mengintegrasikan PLTAn kecepatan tetap pada suatu sistem tenaga listrik. Hasil yang persis sama antara kedua metode tersebut adalah akibat keduanya merupakan metode yang benar dan oleh karenanya nilai-nilainya tidak akan berbeda.

Tabel 9. Daya Listrik Yang Dibangkitkan PLTAn Dengan Kapasitor

\begin{tabular}{ccc}
\hline Pm & Metode Yang Diusulkan & $\begin{array}{c}\text { Metode Jaringan } \\
\text { Dua-Terminal }\end{array}$ \\
\hline 0,1 & $0,0803-\mathrm{j} 0,2870$ & $0,0803-\mathrm{j} 0,2870$ \\
0,2 & $0,1788-\mathrm{j} 0,2995$ & $0,1788-\mathrm{j} 0,2995$ \\
0,3 & $0,2765-\mathrm{j} 0,3172$ & $0,2765-\mathrm{j} 0,3172$ \\
0,4 & $0,3734-\mathrm{j} 0,3401$ & $0,3734-\mathrm{j} 0,3401$ \\
0,5 & $0,4696-\mathrm{j} 0,3684$ & $0,4696-\mathrm{j} 0,3684$ \\
0,6 & $0,5648-\mathrm{j} 0,4024$ & $0,5648-\mathrm{j} 0,4024$ \\
0,7 & $0,6590-\mathrm{j} 0,4429$ & $0,6590-\mathrm{j} 0,4429$ \\
0,8 & $0,7521-\mathrm{j} 0,4907$ & $0,7521-\mathrm{j} 0,4907$ \\
0,9 & $0,8439-\mathrm{j} 0,5475$ & $0,8439-\mathrm{j} 0,5475$ \\
1,0 & $0,9339-\mathrm{j} 0,6159$ & $0,9339-\mathrm{j} 0,6159$ \\
\hline
\end{tabular}

Konfirmasi lebih lanjut ditunjukkan oleh Gambar 5 dimana Gambar 5 tersebut memperlihatkan kurva dari variasi-variasi $P_{g}$ dan $-Q_{g}$ terhadap $P_{m}$ untuk metode yang diusulkan pada Tabel 7 dan 9. Bila dibandingkan dengan kurva pada [7], kurva dari Gambar 5 tersebut adalah juga sangat sesuai. Hal ini juga menunjukkan bahwa metode yang diusulkan adalah akurat dan valid. 


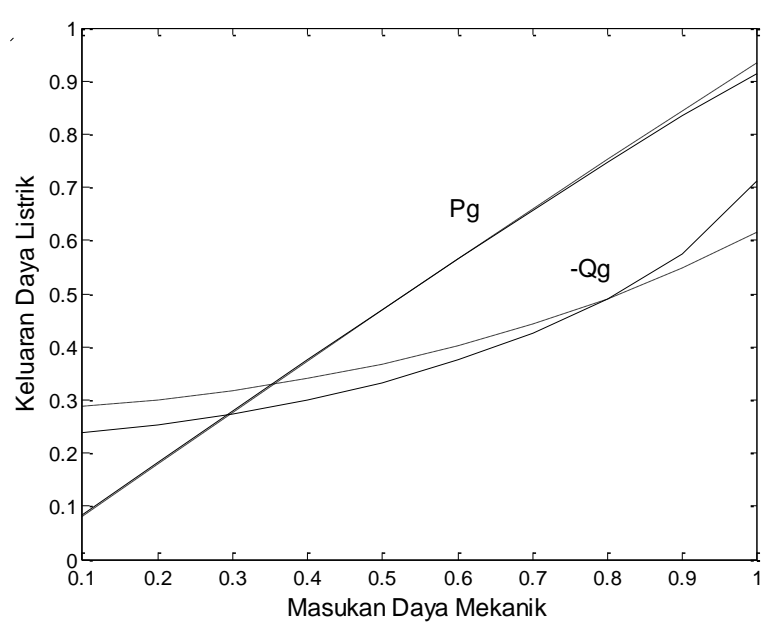

Gambar 5. Variasi Keluaran Daya Listrik PLTAn

----- : dengan kapasitor : tanpa kapasitor

\section{Kesimpulan}

Metode sederhana untuk mengikut-sertakan PLTAn kecepatan tetap pada analisis aliran daya telah disajikan pada makalah ini. Metode yang diusulkan ini didasarkan pada model rangkaian ekivalen-pi generator induksi dari PLTAn tersebut. Kemudian, model untuk PLTAn dibentuk melalui persamaan-persamaan yang diperoleh dari rangkaian ekivalen-pi tersebut. Model rangkaian ekivalen-pi ini diperoleh dari rangkaian ekivalen keadaan tunak generator induksi (rangkaian $\mathrm{T}$ atau $\mathrm{Y}$ ) yang kemudian, melalui transformasi Y-D, dikonversi menjadi rangkaian $\Pi$ (pi) atau $D$. Transformasi ini dilakukan untuk mempermudah penurunan model matematis dari PLTAn tersebut.

Model yang diusulkan ini lebih sederhana dan dapat dengan mudah diikut-sertakan pada algoritma perhitungan aliran daya. Model matematik ini kemudian, bersamasama dengan persamaan aliran daya yang telah ada, diselesaikan secara simultan dengan menggunakan metode Newton-Raphson untuk mendapatkan solusi dari masalah aliran daya secara keseluruhan (termasuk PLTAn). Pengujian pada sistem tenaga listrik yang representatif memperlihatkan bahwa hasil-hasil yang diperoleh dari metode yang diusulkan (model ekivalen-pi) adalah sangat sesuai dengan hasil-hasil dari metode yang sebelumnya telah dipublikasikan (model jaringan duaterminal). Hal ini menunjukkan bahwa metode yang diusulkan tersebut adalah akurat dan valid sehingga dapat digunakan sebagai cara untuk mengintegrasikan model PLTAn pada analisis aliran daya suatu sistem tenaga listrik.

\section{Referensi}

[1] Wind Energy - Statistical Review of World Energy [Online],

https://www.bp.com/en/global/corporate/energyeconomics/statistical-review-of-worldenergy/renewable-energy/wind-energy.html, tanggal akses: 11 Oktober 2018.

[2] World Wind Energy Association - Statistics [Online], https://wwindea.org/blog/2018/02/12/2017-statistics/, tanggal akses: 11 Oktober 2018.

[3] Feijoo, A., Pazos, J.L dan Villanueva, D.,"Conventional Asynchronous Wind Turbine Models - Mathematical Expressions for the Load Flow Analysis", International Journal of Energy Engineering (IJEE), Dec. 2013, 3, (6), pp. 269-278.

[4] Feijoo, A. dan Villanueva, D.,“A PQ Model for Asynchronous Machines Based on Rotor Voltage Calculation", IEEE Trans. Energy Conversion, June 2016, 31, (2), pp. 813-814

[5] Feijoo, A. dan Villanueva, D., "Correction to 'A PQ Model for Asynchronous Machines Based on Rotor Voltage Calculation"', IEEE Trans. Energy Conversion, Sept 2016, 31, (3), pp. 1228-1228.

[6] Gianto, R., Two-Port Network Model of Fixed-Speed Wind Turbine Generator for Distribution System Load Flow Analysis", TELKOMNIKA, 2019, 17, (3), pp. 1569-1575.

[7] Haque, M.H.,“ Incorporation of Fixed Speed Wind Farms in Power Flow Analysis", IET Renewable Power Generation Conference (RPC 2013).

[8] Haque, M.H.,"Evaluation of Power Flow Solutions with Fixed Speed Wind Turbine Generating Systems", Energy Conversion and Management, 2014, 79, pp. 511518.

[9] Haque, M.H.,"Incorporation of Fixed Speed Wind Turbine Generators in Load Flow Analysis of Distribution Systems", International Journal of Renewable Energy Technology, Jan. 2015, 6, (4), pp. 317-324.

[10] Wang, J., Huang, C. dan Zobaa, A.F.,"Multiple-Node Models of Asynchronous Wind Turbines in Wind Farms for Load Flow Analysis", Electric Power Components and Systems, Dec. 2015, 44, (2), pp. 135-141.

[11] Gianto, R., dan Khwee, K.H., A New Method for Load Flow Solution of Electric Power Distribution System", International Review of Electrical Engineering, 2016, 11, (5), pp. 535-541.

[12] Stevenson, W.D., Elements of Power System Analysis, 1992, McGraw- Hill Book Co. Inc., New York.

\section{Lampiran}

Berdasarkan Gambar 3(b), keluaran daya listrik PLTAn adalah:

$$
S_{g}=V_{S} I_{S}^{*}
$$


dan masukan daya mekanik turbin angin diberikan oleh:

$S_{m}=V_{R} I_{R}^{*}$

dimana $I_{S}$ dan $I_{R}$ berturut-turut adalah arus-arus stator dan rotor. Dengan mengamati Gambar 3(b), arus-arus stator dan rotor ini dapat dihitung melalui:

$I_{S}=I_{c}-I_{b}$

$I_{R}=I_{a}+I_{c}$

Oleh karena:

$$
\begin{aligned}
& I_{a}=\frac{V_{R}}{Z_{a}} \\
& I_{b}=\frac{V_{S}}{Z_{b}} \\
& I_{c}=\frac{V_{R}-V_{S}}{Z_{c}}
\end{aligned}
$$

Maka, arus-arus stator dan rotor menjadi:

$$
I_{S}=\frac{1}{Z_{c}} V_{R}-\left(\frac{1}{Z_{b}}+\frac{1}{Z_{c}}\right) V_{S}
$$

$$
I_{R}=\left(\frac{1}{Z_{a}}+\frac{1}{Z_{c}}\right) V_{R}-\frac{1}{Z_{c}} V_{S}
$$

Substitusi (L.8) pada (L.1) dan (L.9) pada (L.2), keluaran daya listrik PLTAn dan masukan daya mekanik turbin angin menjadi:

$$
S_{g}=\frac{1}{Z_{c}^{*}} V_{R}^{*} V_{S}-\left(\frac{1}{Z_{c}^{*}}+\frac{1}{Z_{b}^{*}}\right) V_{S}^{*} V_{S}
$$

$S_{m}=\left(\frac{1}{Z_{c}^{*}}+\frac{1}{Z_{a}^{*}}\right) V_{R}^{*} V_{R}-\frac{1}{Z_{c}^{*}} V_{S}^{*} V_{R}$ 